\title{
MANAJEMEN PERUBAHAN LEMBAGA PENDIDIKAN ISLAM DI ERA GLOBALISASI
}

\author{
Misbah Munir ${ }^{1}$, Ermita Zakiyah ${ }^{2}$ \\ Email: misbahchasbullah@gmail.com²1, zakiyah.ermita@pai.uin-malang.ac.id² \\ Universitas Islam Negeri Maulana Malik Ibrahim Malang
}

\section{Abstract}

This article discusses the change management Institution of Islam in the Era of globalization. The existence of Islamic educational institutions now is faced with various challenges, namely the existence of the current globalization, development of science and technology and the flow of information that is always evolving and constantly growing fast. In this era of technological advancement could not be avoided because of advances in technology will run in accordance with the development of science. Each innovation was created to provide positive benefits to human life. The technology also provides a lot of convenience, as well as a new way of doing human activities. Humans also already enjoy many of the benefits brought by the technological innovations that have been produced in the last decade. An attempt looking for a new idea about change management in Islamic institution certainly is not easy, therefore the need for the support of all parties. An attempt looking for a new idea about change management in Islamic institution certainly is not easy, therefore the need for the support of all parties. MTsN 1 Malang is a madrasah that is able to manage the institution so that it is able to survive as a flagship school of Islam, considering the development of the religion of Islam which should be offset by means of an adequate education to educate the their students are tough, then it is very exciting to be disclosed further through this research, and it is indeed a very appropriate with the title of the study i.e. change management institution of Islam in the era of globalization.

Keyword: Change Management, Islamic Institution, Globalization

\section{Abstrak}

Artikel ini membahas tentang Manajemen Perubahan Lembaga Pendidikan Islam Di Era Globalisasi. Keberadaan lembaga pendidikan Islam sekarang ini dihadapkan pada berbagai tantangan yaitu dengan adanya arus globalisasi, perkembangan ilmu pengetahuan dan teknologi (IPTEK) dan arus informasi yang selalu berkembang secara menerus dan semakin cepat. Pada era ini kemajuan teknologi tak dapat dihindari karena kemajuan teknologi akan berjalan sesuai dengan perkembangan ilmu pengetahuan. Setiap inovasi diciptakan untuk memberikan manfaat positif bagi kehidupan manusia. Teknologi juga memberikan banyak kemudahan, serta sebagai cara baru dalam melakukan aktivitas manusia. Manusia juga sudah menikmati banyak manfaat yang dibawa oleh inovasi-inovasi teknologi yang telah dihasilkan dalam dekade terakhir ini. Upaya mencari sebuah gagasan baru tentang manajemen perubahan di lembaga pendidikan Islam tentu tidaklah mudah, oleh karena itu perlu adanya dukungan dari semua pihak. MTsN I Malang merupakan madrasah yang mampu mengelola lembaganya sehingga mampu bertahan sebagai sekolah unggulan yang bernafaskan Islam, mengingat perkembangan agama Islam yang harus diimbangi dengan sarana pendidikan yang memadai untuk mendidik para siswanya yang tangguh, maka sangatlah menarik untuk diungkap lebih jauh melalui penelitian ini, dan hal ini memang sangat sesuai dengan judul penelitian ini yaitu manajemen perubahan lembaga pendidikan Islam di era globalisasi.

Kata Kunci: Manajemen Perubahan, Lembaga Pendidikan Islam, Era Globalisasi 


\section{Pendahuluan}

Madrasah sebagai salah satu bentuk lembaga pendidikan yang bercorak Islam telah tumbuh dan berkembang menjadi bagian dari kebudayaan bangsa. Melalui proses perjalanan yang cukup panjang kini madrasah telah menjadi salah satu bentuk entitas budaya bangsa Indonesia yang dengan sendirinya menjalani proses sosialisasi yang cukup intensif dengan indikasi bahwa keberadaannya berangsur-angsur namun pasti telah diterima banyak kalangan masyarakat Indonesia. Ia pun telah mampu memasuki arus utama pembangunan bangsa menjelang akhir abad ke-20 ini, dan kemampuan antar madrasah terus meningkat (Maksum, 1999 ). Sekarang ini telah banyak bermunculan madrasahmadrasah unggulan di berbagai daerah dan di kota. Kenyataan ini menegaskan bahwa tingkat persaingan yang berbasis mutu antar madrasah sudah semakin terbuka (Rencana strategis direktorat tenaga kependidikan tahun 2006 - 2010)

Adanya Undang-undang nomor 22 tentang otonomi daerah telah memberikan dan membuka peluang terhadap madrasah untuk mengokohkan dirinya sebagai lembaga pendidikan masyarakat. Madrasah bisa mengembangkan dirinya dalam operasional program pendidikan tanpa adanya intervensi pusat. Sedangkan lahirnya Undang-Undang UU Sisdiknas No 2 Tahun 1989 dan UU Sisdiknas No 20 Tahun 2003 telah memposisikan madrasah menjadi sub sistem pendidikan nasional. Berbagai terobosan dan kebijakan telah diambil Kementerian Agama dalam rangka mempercepat peningkatan mutu pendidikan madrasah (UU 2003 No 20). Salah satunya adalah yang tertuang dalam Rencana Strategis Pendidikan Islam 20102014 yaitu bagaimana meningkatkan mutu dan tata kelola pendidikan madrasah sesuai dengan standar nasional pendidikan sebagaimana diatur oleh PP Nomor 19 Tahun 2005. Untuk itu madrasah perlu berupaya untuk melakukan kerja keras secara terus menerus belajar dan meningkatkan kualitas layanan mutu pendidikan agar tidak ketinggalan dengan pendidikan umum.

Madrasah sebagai salah satu bentuk lembaga pendidikan yang bercorak Islam telah tumbuh dan berkembang menjadi bagian dari kebudayaan bangsa. Madrasah memiliki andil yang sangat besar dalam mencerdaskan bangsa Indonesia sejak zaman penjajahan hingga merdeka sekarang yang akhirnya telah menyatu dalam tata nilai budaya bangsa sebagai modal dasar bagi pembangunan agama yang pengembangannya menuntut pola pembinaan yang berorientasi ke masa depan yang lebih baik. Melalui proses perjalanan yang cukup panjang kini madrasah telah menjadi salah satu bentuk entitas budaya bangsa Indonesia yang dengan sendirinya menjalani proses sosialisasi yang cukup intensif dengan indikasi bahwa keberadaannya berangsurangsur namun pasti telah diterima banyak kalangan masyarakat Indonesia. Ia pun telah mampu memasuki arus utama pembangunan bangsa menjelang akhir abad ke-20 ini, dan kemampuan antar madrasah yang semakin lama terus meningkat (Maksum, 1999). Keberhasilan dalam mencapai mutu pendidikan madrasah ini sangat ditentukan oleh kepemimpinan yang kuat dari masingmasing kepala madrasah, hal ini senada dengan pendapat Crawfond $M$ yang mengatakan bahwa pemimpin yang sukses adalah mereka-mereka yang organisasinya telah berhasil dalam mencapai tujuan (Handoko, 2003). Dalam kenyataannya para pemimpin dapat mempengaruhi moral dan kepuasan kerja, keamanan, kualitas kehidupan kerja dan terutama pada tingkat prestasi suatu organisasi. Pemimpin juga memainkan peranan kritis dalam membantu kelompok, organisasi atau masyarakat untuk mencapai tujuan mereka (Handoko, 2003). Sehingga peranan seorang pemimpin sangat berpengaruh terhadap peningkatan mutu layanan madrasah. Maju dan tidaknya madrasah sangat tergantung kepada kepiwaian seorang kepala madrasah.

Dari latar belakang di atas dapat

kita kaji lebih jauh bagaimana implementasi manajemen perubahan mutu 
madrasah yang sudah dikategorikan unggul di Indonesia. Agar madrasah bisa berkembang di era persaingan global saat ini, diperlukan pengelolaan perbaikan mutu agar mampu bersaing di kancah persaingan nasional maupun internasional. Oleh karenanya madrasah sangat membutuhkan kemampuan untuk peningkatan mutu madrasah dalam upaya penjaminan mutu madrasah.

Dalam upaya mencari sebuah gagasan baru tentang manajemen perubahan di lembaga pendidikan Islam tentu tidaklah mudah, oleh karena itu perlu adanya dukungan dari semua pihak. Pada akhirnya, melalui penelitian ini, diharapkan dapat menghasilkan sebuah solusi tentang manajemen perubahan di lembaga pendidkan Islam di era globalisasi.

\section{Pembahasan}

\section{Konsep Manajemen Perubahan \\ a. Pengertian manajemen}

Pada dasarnya kemampuan manusia itu terbatas (fisik, pengetahuan, waktu dan perhatian) sedangkan kebutuhannya tidak terbatas. Usaha untuk memenuhi kebutuhan dan terbatasnya kemampuan dalam melakukan pekerjaan mendorong manusia membagi pekerjaan, tugas, dan tanggung jawab. Dengan adanya pembagian pekerjaan, tugas dan tanggung jawab ini maka terbentuklah kerjasama dan ketertarikan formal dalam suatu organisasi. Dalam organisasi ini maka pekerjaan yang berat dan sulit akan dapat diselesaikan dengan baik serta tujuan yang diinginkan tercapai.

Manajemen pada dasarnya sudah ada sejak adanya pembagian kerja, tugas, tanggungjawab dan kerja sama formal dari sekelompok orang untuk mencapai tujuan. Tegasnya, manajemen sudah ada sejak adanya pemimpin/ pengatur dan bawahan yang diatur untuk mencapai tujuan bersama, walaupun masalahnya masih sangat sederhana.

Karena demikian pentingnya sebuah manajemen maka hal ini mendorong para ilmuwan untuk mengadakan penelitian tentang manajemen. Manajemen berasal dari kata to manage yang artinya mengatur. Pengaturan dilakukan melalui proses dan diatur berdasarkan urutan dari fungsifungsi manajemen itu. Jadi Manajemen merupakan suatu proses untuk mewujudkan tujuan yang di inginkan. Menurut Andrew F. Sikula,

Management in general refers to planning, organizing, controlling, staffing, leading, motivating, communicating, and decision making activities performed by any organization in order to coordinate the varied resources of the enterprise so as to bring an efficient creation of some product or service.

Artinya :

Manajemen pada umumnya dikaitkan dengan aktivitas-aktivitas perencanaan, pengorganisasian, pengendalian, penempatan, pengarahan, pemotivasian, komunikasi dan pengambilan keputusan yang dilakukan oleh setiap organisasi dengan tujuan untuk mengkoordinasikan berbagai sumber daya yang dimiliki oleh perusahaan sehingga akan dihasilkan suatu produk atau jasa secara efisien.

Menurut G.R. Terry, konsep manajemen didefinisikan sebagai berikut :

Management is a distinct process consisting of planning, organizing, actuating and controlling performed to determine ang accomplishe stated objectives by the use of human being and other resources.

Artinya :

Manajemen adalah suatu proses yang khas yang terdiri dari tindakan-tindakan perencanaan, pengorganisasian, pengarahan, dan pengendalian yang dilakukan untuk menentukan serta mencapai sasaran-sasaran yang telah ditentukan melalui pemanfaatan sumber daya manusia dan sumber-sumber lainnya.

Adapun menurut Harold Koontz dan Cyril O'Donnel :

Management is getting things done through people. In bringing about this coordinating of group activity, the manager, as a manager 
plans, organizes, staffs, direct and control the activities other people.

Artinya :

Manajemen adalah usaha mencapai suatu tujuan tertentu melalui kegiatan orang lain. Dengan demikian manajer mengadakan koordinasi atas sejumlah aktivitas orang lain yang meliputi perencanaan, pengorganisasian, penempatan, pengarahan, dan pengendalian (Hasibuana, 2001).

Beberapa ahli yang lain merumuskan manajemen sebagai berikut : Menurut Stonner dan Wankel, manajemen adalah proses merencanakan, mengorganisasikan, memimpin, mengendalikan usaha-usaha anggota organisasi dan proses penggunaan sumber daya organisasi untuk mencapai tujuantujuan organisasi yang sudah di tetapkan(Seregar, dkk, tanpa tahun).

Harold Koontz dan C.O Donnel dalam bukunya "Priciples of Management An Analysis of Managerial Functions" mendefinisikan manajemen sebagai berikut :

Management is the accomplishment of desired objectives by establishing an environment favorable to performance by people operating in organized group (dalam burhannudin, 1994).

Artinya :

Manajemen adalah sebuah usaha pencapaian tujuan yang diinginkan dengan membangun suatu lingkungan (suasana) yang menyenangkan terhadap pekerjaan yang dilakukan oleh orang-orang dalam kelompok terorganisir.

Dari sekian banyak definisi tersebut dapat dikatakan bahwa permasalahan manajemen berkaitan dengan usaha untuk memelihara kerjasama sekelompok orang dalam satu kesatuan serta usaha untuk memanfaatkan sumber daya yang lain untuk mencapai tujuan-tujuan tertentu yang telah ditetapkan sebelumnya. Dengan demikian sebenarnya kegiatan manajemen itu hampir selalu ada pada setiap kegiatan manusia, sebab sebagai makhluk sosial manusia akan selalu berusaha berkumpul dan bekerjasama. Dengan demikian dapat dikatakan bahwa untuk menjalankan suatu organisasi, apapun bentuk organisasi tersebut dibutuhkan suatu manajemen.

Pola dasar manajemen paradigma baru melalui proses POAC, yaitu Planning, Organizing, Actuating, dan Controlling, selanjutnya didukung proses penggunaan sumber daya 6M, yaitu Men, Money, Materials, Machines, Methods, dan Markets, dan pengembangan serta perbaikan (improving) terus-menerus agar menjadi lebih baik.

\section{b. Perencanaan}

Perecanaan adalah penentuan secara matang dan cerdas tentang apa yang akan di kerjakan di masa yang akan datag dalam rangka mencapai tujuan.

1. Sumber-sumber perencanaan

Perencanaan di buat berdasarkan atas beberapa sumber antara lain:

a. Kebijaksanaan pucuk pimpinan (policytopmanagement)

Bahwa perencanaan itu sering kali berasal dari badan-badan ataupun orang-orang yang berhak dan mempunyai wewenang untuk membuat kebijakan

b. Hasil pengawasan, yaitu suatu perencanaan yang di buat atas dasar akta-fakta maupun data-data dari hasil pengawasan suatu kegiatan kerja.

c. Kebutuhan masa depan, yaitu perencanaan sengaja di buat untuk memepersiapkan masa depan yang lebih baik dan unutk mengatasi halangan yang akan dating

d. Penemuan-penemuan baru, yaitu perencanaan yang di buat berdasarkan study factual dan terus menerus sehingga menemukan ide-ide baru

2. Kategori perencanaan

Ada sejumlah kategori perencanaan yang perlu di ketahuai, yaitu:

a. Perencanaaan fisik, adalah perencanaan yang berhubungan dengan sifat-sifat serta peraturan material gedung dan alat-alat. Misalnya perencanaan kota, perencanaan regional, dll.

b. Perencanaan fungsional, adalah perecznaan yang berhubungan dengan 
fungsi atau tugas-tugas tertentu. Isalnya planning produksi, pemasaran dll.

c. Perencanaan secara luas, adalah perencanaan yang mencakup kegiatankegiatan secara keseluruhan yang mencakup intern maupun ekstern

d. Perencanaan yang di kombinasikan, adalah perencanaan yang meliputi berbagai unsur dari perencanaan dan di kombinasikan sedemikian rupa menjadi satu pola yang lengkap dan sempurna.

\section{c. Pengorganisasian}

Menurut Hikcs\&Gullet (181:321)

mengatakan bahwa pengorganisasian adalah kegiatan membagi tugas, tanggung jawab, wewenang di antara sekelompok orang untuk mencapai tujuan yang telah di tetapkan.Gordon, mondy Sharplin dan premeaux (190:20) mengatakn bahwa pengorganisasian ialah proses menetapkan hubungan formal di antara orang-orang dan sumber-sumber kea rah percapaian tertentu

1. Unsur-unsur organisasi

Organisasi adalah hubungan structural yang mengikat unsur-unsur sebagai berikut:

a. Manusia berpa unsur yang bekerjasama, ada pimpinan da nada yang di pimpin dan seterusnya

b. Sasaran yakni tujuan yang ingin di capai

c. Tempat kedudukan di mana manusia memiliki peran wewenang dan tugasnya

d. Pelajaran dan wewenang sesuai dengan peran dan kedudukannya yang di susun dalampembagian tugas

e. Teknologi yakni berhubungan antara manusia yang satu dengan yang lain sehingga tercipta organisasi

f. Lingkungan yakni adanya lingkungan yang saling mempengaruhi

2. Prinsip-prinsip pengorganisasian Siaigan (1990) menyebutkan bahwa ada 15 prinsip organisasi, yakni

a. Kejelasan tujuan yang ingin di capai

b. Pemahaman tujuan oleh para anggota organisasi

c. Penerima tujuan oleh para anggota organisasi

d. Adanya kesatuan arah

e. Kesatuan perintah f. Fungsionalisasi

g. Deleniasi berbagai tugas

h. Keseimbanagan antara wewenang dan tanggung jawab

i. Pembagian tugas

j. Kesederhanaan struktur

k. Pola dasar organisasi yang relative permanen

l. Adanya pola pendelegasian wewenang

$\mathrm{m}$. Rentang pengawasan

n. Jaminan pekerjaan

o. Keseimbangan antar jasa dan imbalan

\section{d. Penggerakan}

Pengertian penggerakan menurut Koontz \& O'Donnel (dalam Hasibuan,1989) adalah hubungan erat antara aspek-aspek individual yang di timbulkan dari adanya pengaturan terhadap bawahan untuk dapat di mengerti dan pembagian kerja yang efektif dan efisisen untuk mencapai tujuan perusahaan yng nyata.

\section{e. Pengendalian}

Secara etimologis controlling oleh George R.Terry di terjemahkan sebagai suatu usaha untukk meneliti kegiatan-kegiatan yang akan di laksanakan.

1. Prinsip-prinsip pengendalian

a. Prinsip tercapainya tujuan

b. Prinsip efesiensi pengendalian

c. Prinsip tanggung jawab pengendalian

d. Prinsip pengendalian terhadap masa depan

e. Prinsip pengendalian langsung

f. Prinsip refleksi perencanaan

g. Prinsip penyesuaian dengan organisasi

h. Prinip pengendalian individual

2. Proses pengendalian

a. Menentukan standar atau dasardasar control

b. Mengukur pelaksanaan kerja

c. Membandingkan pelaksanaan dengan standard an deviasi-deviasai pabila terjadi sesuatu

d. Melakukan tindakan-tindakan perbaikan jika terdapat penyimpangan agar pelaksanaan dan tujuan sesuai dengan rencana.

\section{Perubahan}

Era globalisasi telah membawa dampak dalam berbagai perubahan yang 
sarat dengan tantangan, peluang, dan persaingan ketat. Keharusan untuk melaksanakan perubahan dewasa ini dalam lingkungan pendidikan adalah sebuah fakta kehidupan bagi semua lembaga sekarang ini tidak boleh menunggu hingga mereka mengalami proses kemunduran dan barulah mereka melaksanakan perubahan-perubahan, mereka secara terus menerus perlu memprediksi dan mengantisipasi kebutuhan akan perubahan.

Perubahan bisa kita artikan bahwa perubahan senantiasa mengandung makna beralihnya keadaan sebelumnya _the before condition) menjdi keadaan setelahnya (the after condition) (Winardi, 2010). Perubahan itu sendiri adalah membuat sesuatu menjadi berbeda, perubahan merupakan pergeseran dari keadaan sekarang suatu organisasi menuju pada keadaan yang diinginkan dimasa depan (Wibowo, 2006). Dengan kata lain bahwa terjadi perubahan dari kondisi lama (status quo) menjadi kondisi baru (reformis). Perubahan bisa terjadi secara evolusioner tetapi dapat pula berlangsung secara revolusioner (Winardi, 2010). Kondisi tersebut jelas akan mempengaruhi nilai tatanan lembaga pendidikan, Oleh karena itu, perlu berevolusi terhadap perubahan dengan menciptakan perubahan yang terencana dan selanjutnya melakukan reformasi di segala bidang sehingga lembaga pendidikan menjadi dinamis, reformis, dan selalu dalam kondisi terbaru (the new).

Perubahan keorganisasian merupakan tindakan beralihnya sesuatu organisasi dari kondisi yang berlaku kini menuju kondisi yang akan datang yang diinginkan guna meningkatkan efektifitasnya. Dalam lembaga pendidikan seseorang yang berhak bertanggung jawab dalam proses perubahan adalah pimpinan lembaga atau kepala sekaolah. Kepala sekolah dengan kekuasaan dan kewenangannya berhak untuk melakukan perubahan. Perubahan bisa terjadi melalui perubahan yang direncanakan atau perubahan yang tidak direncanakan. Perubahan yang tidak direncanakan terjadi secara sepontan atau secara acak, dan ia terjadi tanpa perhatian seorang pimpinan. Perubahan yang demikian bisa merusak. Perubahan yang lebih penting terjadi di lembaga adalah perubahan yang direncanakan. Perubahan yang direncanakan adalah merupakan reaksi langsung terhadap pemikiran atau persepsi seseorang tentang kinerja, maksudnya pemikiran yang diinginkan dengan keadaan nyata (Winardi, 2010). Perubahan dalam organisasi sering diartikan sebagai mengubah organisasi, artinya melibatkan suatu proses di mana kita memodifikasi guna meningkatkan keefektifan organisasi. Hal tersebut dimaksudkan tingkat atau derajat organisasi tersebut mampu mencapai sasarannya. Dalam lembaga pendidikan di dalam memodifikasi lembaga tersebut mampu mencapai segmen-segmen keorganisasian, tingkat-tingkat tanggung jawab dan garis-garis komunikasi yang telah di tetapkan sebelumnya. Untuk mencapai keberhasilan maka lembaga pendidikan harus selalu melakukan perubahan, hal ini sebagai reaksi atas perkembangan-perkembangan penting seperti kebutuhan para pelanggan, penemuan-penemuan teknologi baru, dan kebijakan-kebijakan pemerintah (Winardi, 2010).

Dalam melakukan perubahan dalam lembaga pendidikan perlu adanya peran seorang pemimpin yang mampu melakukan perubahan. Hal ini sangat penting mengingat pendidikan diyakini mampu memberdayakan secara terpadu dan berkesinambungan dalam pembentukan karakter. Di satu sisi pendidikan harus mampu mempunyai wawasan pemikiran yang jauh kedepan, mampu membaca peluang dan tantangan global, sedangkan disi yang lain upaya upaya untuk memelihara perilaku etik pribumi tetap dipertahankan. Pendidikan dalam perspektif global merupakan suatu keharusan. Dalam konsep manajemen berbasis sekolah (MBS) telah memberikan gambaran yang jelas bahwa sekolah harus dibangun atas dasar visi dan misi yang berorintasi jauh ke depan memiliki arti bahwa pendidikan selain mempertahankan citra ideal warga Negara 
dan warga masyarakat yang baik juga diperluas menjadi warga dunia yang baik, sehingga mencapai nilai-nilai moral universal. Orientasi pendidikan tersebut diperlukan agar manusia Indonesia tidak menjadi objek perubahan dalam tatanan global (Mulyana, 2004). Hai ini tentunya sekolahan memperlukan seorang pemimpin yang mampu mempengaruhi, mendorong, mengajak, menuntun, menggerakan, mengarahkan, anggotanya dalam mencapai sasaran atau tujuan tersebut.

Faktor perubahan secara menyeluruh dalam organisasi mencakup enam variabel yang saling berinteraksi yang dapat dimanfaatkan dalam fokus perubahan terencana yaitu Manusiakultur-tugas-tugas, teknologi, desain dan startegi. Variabel manusia berlaku bagi para individu yang bekerja dalam organisasi yang bersangkutan. Variabel kultur merefleksi keyakinan bersama, nilai-nilai, norma-norma para anggota keorganisasian. Variabel tugas mencakup dari sifat pekerjaan itu sendiri apakah pekerjaan itu bersifat sederhana atau kompleks. Variabel teknologi mencakup metode-metode pemecahan masalah dn teknik-teknik yang diterapkan untuk penerapan pengetahuan terhadap berbagai macam proses keorganisasian. Mencakup dari pemanfaatan teknologi informasi, dan alat-alat otomatis lainnya. Variabel desain adalah berkaitan dengan struktur keorganisasian formal dan systemsistemnya berupa komunikasi, pengendalian dan otoritas dan tanggung jawab. Terakhir adalah variabel strategi, mencakup proses perencanaan organisasi yang bersangkutan, secara tipikal ia terdiri dari kegiatan-kegiatan yang dilaksanakan guna mengidentifikasi tujuan-tujuan keorganisasian dan dipersiapkannya rencana-rencana spesifik guna mencapai, mengalokasi, dan memanfaatkan sumber daya dalam mencapai tujuan-tujuan yang telah ditentukan (Winardi, 2010). Keenam variabel tersebut menunjukkan dengan jelas adanya hubungan yang interdependen. Sebuah perubahan pada variabel tertentu biasanya menyebabkan timbulnya perubahan pada salah satu variabel yang lain atau variabel-variabel lainnya.

\section{Era Globalisasi}

Abad 21 dikenal sebagai era globalisasi. Era globalisasi bukan hanya tantangan , tetapi juga sekaligus mempunyai peluang. Globalisasi memiliki implikasi yang luas tehadap penghidupan dan kehidupan berbangsa dan bernegara, baik ideologi, politik, ekonomi, sosial budaya, maupun pertahanan keamanan.

Era adalah masa atau kurun waktu, sejumlah tahun dalam kurun waktu antara beberapa peristiwa penting. Istilah globlisasi berasal dari kata globe (peta dunia yang berbentuk bola). Dari kata globe selanjutnya lahir istilah global (yang artinya meliputi seluruh dunia). Dari kata global lahirlah istilah globalisasi, yang bermakna sebuah proses mendunia. Globalisasi adalah suatu proses dibentuknya suatu tatanan, aturan, dan sistem yang berlaku bagi bangsa-bangsa di seluruh dunia.Globalisasi digambarkan sebagai semua proses yang merujuk kepada penyatuan seluruh warga dunia menjadi sebuah kelompok masyarakat global. Dengan didukung teknologi komunikasi yang begitu canggih, dampak globalisasi tentu akan sangat kompleks. Manusia begitu mudah berhubungan dengan manusia lain di manapun di dunia ini. Berbagai barang dan informasi dengan berbagai tingkatan kualitas tersedia untuk dikonsumsi. Akibatnya akan mengubah pola pikir, sikap dan tingkah laku manusia. Hal seperti ini kemungkinan dapat mengakibatkan perubahan aspek kehidupan yang lain seperti hubungan kekeluargaan, kemasyarakatan, kebangsaan, atau secara umum berpengaruh pada sistem budaya bangsa.

Dalam abad ini Soedjatmoko menggambarkan adanya sifat-sifat dan kemampuan yang harus dimiliki manusia Indonesia di masa mendatang sebagai berikut.

a. Orang harus serba tahu (well informed), dan harus selalu menyadari bahwa proses belajar tidak akan pernah selesai di dalam dunia yang terus berubah secara 
sangat cepat. Dia harus mampu mencerna informasi yang banyak tapi tuntas, itu artinyaharus mempunyai kemampuan analisis yang tajam, mampu berpikir integratifserta dapat bereaksi cepat.

b. Orang harus kreatif dalam memberikan jawaban terhadap tantangan baru, serta mempunyai kemampuan mengantisipasi setiap perkembangan.

c. Mempunyai kepekaan terhadap keadilan sosial dan solidaritas sosial. Peka terhadap batas-batas toleransi masyarakat serta terhadap perubahan sosial dan ketidakadilan.

d. Memiliki harga diri dan kepercayaan pada diri sendiri berdasarkan iman yang kuat.

e. Sanggup mengidentifikasi dimensidimensi moral dan etis dalam perubahan sosial dan pilihan teknologi. Selanjutnya juga sanggup menginterpretasikan ketentuan-ketentuan agama sehingga terungkaplah relevansinya dalam pemecahan masalah dan perkembanganperkembangan baru.

Sebagai perbandingan Ulrih Teicher (1997) mengemukakan bahwa manusia masa depan harus mempunyai persyaratan kualitas dan kemampuan sebagai berikut.

a. Fleksibel.

b. Mampu dan bersedia untuk berpartisipasi dalam inovasi serta menjadi kreatif.

c. Mampu menguasai hal-hal yang tidak menentu atau seringkali berubah-ubah.

d. Tertarik dan siap belajar seumur hidup.

e. Memiliki kepekaan sosial dan keterampilan berkomunikasi.

f. Mampu bekerja dalam tim.

g. Mampu mengambil tanggung jawab yang diserahkan padanya.

h. Mampu menyiapkan diri untuk melakukan internasionalisasi pasaran kerja melalui pengertiannya tentang macammacam budaya.

i. Cakap dalam bebagai hal, baik keterampilan umum, maupun keterampilan profesional.

\section{Manajemen perubahan di MTsN 1 Malang}

Pada dasarnya kemampuan manusia itu terbatas (fisik, pengetahuan, waktu dan perhatian) sedangkan kebutuhannya tidak terbatas. Usaha untuk memenuhi kebutuhan dan terbatasnya kemampuan dalam melakukan pekerjaan mendorong manusia membagi pekerjaan, tugas, dan tanggung jawab. Dengan adanya pembagian pekerjaan, tugas dan tanggung jawab ini maka terbentuklah kerjasama dan ketertarikan formal dalam suatu organisasi. Dalam organisasi ini maka pekerjaan yang berat dan sulit akan dapat diselesaikan dengan baik serta tujuan yang diinginkan tercapai.

Manajemen pada dasarnya sudah ada sejak adanya pembagian kerja, tugas, tanggungjawab dan kerja sama formal dari sekelompok orang untuk mencapai tujuan. Tegasnya, manajemen sudah ada sejak adanya pemimpin/ pengatur dan bawahan yang diatur untuk mencapai tujuan bersama, walaupun masalahnya masih sangat sederhana.

Karena demikian pentingnya sebuah manajemen maka hal ini mendorong para ilmuwan untuk mengadakan penelitian tentang manajemen. Manajemen berasal dari kata to manage yang artinya mengatur. Pengaturan dilakukan melalui proses dan diatur berdasarkan urutan dari fungsifungsi manajemen itu. Jadi Manajemen merupakan suatu proses untuk mewujudkan tujuan yang di inginkan

Menurut Rohmad Mulyana yaitu dalam melakukan perubahan dalam lembaga pendidikan perlu adanya peran seorang pemimpin yang mampu melakukan perubahan. Hal ini sangat penting mengingat pendidikan diyakini mampu memberdayakan secara terpadu dan berkesinambungan dalam pembentukan 
karakter. Di satu sisi pendidikan harus mampu mempunyai wawasan pemikiran yang jauh kedepan, mampu membaca peluang dan tantangan global, sedangkan disisi yang lain upaya upaya untuk memelihara perilaku etik pribumi tetap dipertahankan. Pendidikan dalam perspektif global merupakan suatu keharusan. Dalam konsep manajemen berbasis sekolah (MBS) telah memberikan gambaran yang jelas bahwa sekolah harus dibangun atas dasar visi dan misi yang berorintasi jauh ke depan memiliki arti bahwa pendidikan selain mempertahankan citra ideal warga Negara dan warga masyarakat yang baik juga diperluas menjadi warga dunia yang baik, sehingga mencapai nilai-nilai moral universal.

Berdasarkan pada hasil pengumpulan data di MTsN I Malang manajemen perubahan diawali dengan penetapan visi yang jauh ke depan dan dijadikan sebagai pijakan dalam pengembangan madrasah, visi madrasah di MTsN I Malang adalah berkualitas unggul dalam IMTAQ dan IPTEK yang berstandar Internasional. Dari visi tersebut kemudian di perjelas ke dalam misi lembaga yaitu:

1. Menyelenggarakan pendidikan sesuai dengan Sistem Pendidikan Nasional dan berstandarInternasional.

2. Menyelenggarakan pendidikan yang dilandasi nilai keislaman dan seni budaya bangsa.

3. Melaksanakan peningkatan kompetensi tenaga pendidik dan kependidikan sesuai standar nasional dan internasional.

4. Melaksanakan pembelajaran yang berkualitas, berbasis ICT dengan menggunakan bahasaInggris.

5. Melaksanakan pengembangan institusi berdasar Manajemen Peningkatan Mutu Berbasis Madrasah (MPMBM).

6. Meningkatkan budaya hidup sehat untuk mewujudkan generasi yang kompetitif.

7. Mewujudkan lulusan yang berakhlakulkarimah, berkualitas, dan berwawasan global.
Berdasarkan pada analisis tersebut di atas bahwa dalam melakukan manajemen perubahan tak lepas dari adanya visi misi lembaga hal ini juga sesuai dengan apa yang disampaikan Rohmad mulyana bahwa seorang pemimpin harus mampu melakukan perubahan di lembaga pendidikan dan pendidikan harus mampu mempunyai wawasan pemikiran yang jauh kedepan, mampu membaca peluang dan tantangan global, sedangkan disisi yang lain upaya upaya untuk memelihara perilaku etik pribumi tetap dipertahankan. Dari visi dan misi tersebut kemudian dijadikan sebagai langkah-langkah strategis dalam bentuk program kegiatan lembaga yang tertuang dalam renstra. Di MTsN 1 Malang renstra tersebut meliputi delapan poin yang terakumulasi menjadi langkah-langkah strategis yang dilakukan yaitu:

1. Standar isi.

Untuk standar isi ini berupa kurikulum, di MTsN I Malang karena Madrasah ini di bawah naungan kemenag, dalam masalah kurikulum agama di MTsN I Malang mengikuti KMA (keputusan menteri agama), sedangkan kurikulum umum menganut kurikulum Diknas (BSPN). Selain itu di MTsN I Malang juga mengeluarkan kurikulum lokal atau muatan lokal yaitu yang meliputi kebahasaan. Kebahasaan yang dimaksud disini adalah seperti bahasa inggris, karya ilmiah remaja (KIR), keinsoklopediaan. Kebijakan lokal itulah yang membuktikan bahwa MTsN I Malang sejalan dengan perkembangan zaman yang global, dengan pembelajaran bahasa inggris ini kemudian diharapkan bisa meningkatkan kemampuan siswa sebagai alat transformasi verbal kepada siswa yang ada di luar negeri. Kurikulum lokal tersebut diterapkan dalam struktur kurikulum MTsN I Malang

2. Standar proses pembelajaran.

Di MTsN I Malang untuk meningkatkan kualitas mutu pembelajaran telah melakukan beberapa proses pembuatan PTK, melakukan supervise, selain itu juga melakukan Pembinaan komunikasi 
dalam bahasa Inggris bagi seluruh warga madrasah, Pendampingan guru dalam pembelajaran dan microteaching di MBI (Madrasah Bertaraf Internasional)

3. Standar kelulusan.

Hal ini di mulai dari pembinaan kepada siswa. Pembinaan tersebut meliputi bakat minat siswa misalnya adanya pembinaan siswa yang berprestasi, bimbingan konseling/kepribadian dan akademik. Hal ini untuk menunjang lulusan yang berkarakter, bukan hanya pintar dalam hal akademis, akan tetapi juga masalah spiritual.

4. Standar pendidik dan kependidikan. Untuk standar pendidik dan kependidikan di MTsN I Malang juga melakukan Penyusunan perencanaan karier yang utuh dan baku. Melakukan penilaian kinerja, Menyusun perencanaan pengembangan SDM, Mengembangkan sistem informasi kepegawaian.

5. Standar sarana dan prasarana.

Di MTsN I Malang program pengadaan, pemeliharaan dan pengembangan sarana dan prasarana sesuai standar SBI

6. Standar Pengelolaan

Program standar pengelolaan di MTsN I Malang meliputi perevitalisasian sistem pengelolaan dan penilaian secara bertahap dan kontinyu menuju standar internasional, Penyusunan standar operasional prosedur (SOP) bidang pengelolaan, dan penyempurnakan Renstra dan Database.

7. Standar Pembiayaan.

Dana MTsN I Malang mempunyai dua sumber, pertama: dari dipa dan dari komite, dipa adalah dana dari pemerintah dalam hal ini bersifat resmi dan yang kedua atau dana dari komite berupa dana bantuan dari masyrakata ataupun dari sponsor yang penggunaannya sesuai dengan kebutuhan yang ada.

8. Standar penilaian.

Di Era globalisasi telah membawa dampak dalam berbagai perubahan yang sarat dengan tantangan, peluang, dan persaingan ketat. Keharusan untuk melaksanakan perubahan dewasa ini dalam lingkungan pendidikan adalah sebuah fakta kehidupan bagi semua lembaga sekarang ini tidak boleh menunggu hingga mereka mengalami proses kemunduran dan barulah mereka melaksanakan perubahanperubahan, mereka secara terus menerus perlu memprediksi dan mengantisipasi kebutuhan akan perubahan. Perubahan bisa kita artikan bahwa perubahan senantiasa mengandung makna beralihnya keadaan sebelumnya the before condition) menjdi keadaan setelahnya (the after condition). Perubahan itu sendiri adalah membuat sesuatu menjadi berbeda, perubahan merupakan pergeseran dari keadaan sekarang suatu organisasi menuju pada keadaan yang diinginkan dimasa depan. Faktor perubahan secara menyeluruh dalam organisasi mencakup enam variabel yang saling berinteraksi yang dapat dimanfaatkan dalam fokus perubahan terencana yaitu Manusiakultur-tugas-tugas, teknologi, desain dan startegi. Variabel manusia berlaku bagi para individu yang bekerja dalam organisasi yang bersangkutan. Variabel kultur merefleksi keyakinan bersama, nilai-nilai, norma-norma para anggota keorganisasian. Variabel tugas mencakup dari sifat pekerjaan itu sendiri apakah pekerjaan itu bersifat sederhana atau kompleks. Variabel teknologi mencakup metode-metode pemecahan masalah dn teknik-teknik yang diterapkan untuk penerapan pengetahuan terhadap berbagai macam proses keorganisasian. Mencakup dari pemanfaatan teknologi informasi, dan alat-alat otomatis lainnya. Variabel desain adalah berkaitan dengan struktur keorganisasian formal dan systemsistemnya berupa komunikasi, pengendalian dan otoritas dan tanggung jawab. Terakhir adalah variabel strategi, mencakup proses perencanaan organisasi yang bersangkutan, secara tipikal ia terdiri dari kegiatan-kegiatan yang dilaksanakan guna mengidentifikasi tujuan-tujuan keorganisasian dan dipersiapkannya rencana-rencana spesifik guna mencapai, mengalokasi, dan memanfaatkan sumber 
daya dalam mencapai tujuan-tujuan yang telah ditentukan.

Abad 21 dikenal sebagai era globalisasi. Era globalisasi bukan hanya tantangan, tetapi juga sekaligus mempunyai peluang. Globalisasi memiliki implikasi yang luas tehadap penghidupan dan kehidupan berbangsa dan bernegara, baik ideologi, politik, ekonomi, sosial budaya, maupun pertahanan keamanan.

Era adalah masa atau kurun waktu, sejumlah tahun dalam kurun waktu antara beberapa peristiwa penting. Istilah globlisasi berasal dari kata globe (peta dunia yang berbentuk bola). Dari kata globe selanjutnya lahir istilah global (yang artinya meliputi seluruh dunia). Dari kata global lahirlah istilah globalisasi, yang bermakna sebuah proses mendunia. Globalisasi adalah suatu proses dibentuknya suatu tatanan, aturan, dan sistem yang berlaku bagi bangsa-bangsa di seluruh dunia.Globalisasi digambarkan sebagai semua proses yang merujuk kepada penyatuan seluruh warga dunia menjadi sebuah kelompok masyarakat global. Dengan didukung teknologi komunikasi yang begitu canggih, dampak globalisasi tentu akan sangat kompleks. Manusia begitu mudah berhubungan dengan manusia lain di manapun di dunia ini. Berbagai barang dan informasi dengan berbagai tingkatan kualitas tersedia untuk dikonsumsi. Akibatnya akan mengubah pola pikir, sikap dan tingkah laku manusia. Hal seperti ini kemungkinan dapat mengakibatkan perubahan aspek kehidupan yang lain seperti hubungan kekeluargaan, kemasyarakatan, kebangsaan, atau secara umum berpengaruh pada sistem budaya bangsa.

Di MTsN I Malang untuk mengadapi arus globalisasi yang semakin cepat sekarang ini berpijak pada pemikiran bahwa setiap lembaga tak mungkin mampu menghindar, dan merupakan sebuah keharusan bagi semua lembaga untuk mengikuti perguliran arus globalisasi yang di tandai dengan adanya ilmu pengetahuan dan teknologi (IPTEK) sehingga lembaga pendidikan harus meningkatkan dirinya agar selalu mampu mengikuti perkembangan zaman. MTsN I Malang dalam menghadapi era globalisasi telah melakukan langkah-langkah strategis yaitu dengan melakukan MOU atau bekerja sama dengan negara tetangga seperti Malaysia hal ini diharapkan MTsN I Malang mampu berkembang di tingkat internasional. Selain mengadakan kerjasama dengan Negara Malaysia MTsN I Malang juga mengembangkan kerjasama dengan Negara lain seperti Australia dan Belanda, hal ini diharapkan MTsN I Malang mampu membawa lembaganya pada tingkat internasional.

Selain itu juga dalam pengembangan manajemen perubahan di MTsN I Malang juga melakukan kegiatan/program seperti Peningkatan kualitas Madrasah Bertaraf Internasional, yang meliputi Workshop pengembangan KTSP (Dokumen-1 KTSP) bertaraf internasional, Penyusunan perangkat pembelajaran (KTSP-Dok 2) sesuai dengan pengembangan kurikulum berstandar internasional, Penyusunan Bahan Ajar Modul yang sesuai dengan KTSP, Peningkatan pelaksanaan penjaminan mutu di madrasah. Melakukan peningkatan proses pembelajaran yang meliputi penyusunan Lesson Plan dan worksheet, Pembinaan komunikasi dalam bahasa Inggris bagi seluruh warga madrasah, Pendampingan guru dalam pembelajaran dan micro teaching di MBI. Melakukan kegiatan Peningkatan mutu pembelajaran, melalui audit proses pembelajaran yang berstandar internasional yang meliputi Pelaksanaan PTK, Supervisi oleh kepala madrasah, Lesson Study, Supervisi oleh lembaga eksternal yang berkompeten. Melakukan perencanaan pengembangan SDM yang meliputi Sosialisasi tentang ISO dari tim ahli (konsultan), Merancang kegiatan menuju standar ISO. Melakukan pengembangan sistem pengelolaan yang sesuai standar internasional yang meliputi Mengikuti workshop manajemen SBI, Mendatangkan konsultan, Studi banding. Sistem pengelolaan budaya sekolah: Language Day, Labelisasi lingkungan sekolah dengan bahasa Inggris, Pembelajaran tartil, hafalan dan terjemah Al Qur'an, Pembiasaan berakhlakul karimah. Selain itu juga melakukan 
kegiatan sistem pengelolaan dan penilaian secara bertahap dan kontinyu menuju standar internasional. Hal ini diharapkan bahwa di MTsN I Malang mampu mengikuti perkembangan di era globalisasi dan mampu memberikan pembiasaan pada masyarakat madrasah untuk melakukan pekerjaan yang professional.

Selain itu juga di MTsN I Malang dalam menghadapi perkembangan ilmu pengetahuan dan teknologi juga membekali siswa siswinya dengan pengayaan/pembelajaran computer hal ini diharapkan siswa siswi tidak ketinggalan dalam dunia teknologi dan selalu mampu meningkatkan keilmuannya melalui teknologi komunikasi yang canggih. Selain itu juga adanya pembinaan siswa yang berprestasi, bimbingan konseling/ kepribadian dan akademik. Hal ini untuk menunjang lulusan yang berkarakter, bukan hanya pintar dalam hal akademis, akan tetapi juga masalah spiritual. Melakukan manajemen pengelolaan masalah, hal ini meliputi: tahapan koordinasi wali kelas, yaitu pengelolaan masalah di lakukan siswa siswi harus di ketahui wali kelas masing-masing, kemudian melakukan tahapan pemanggilan orang tua pihak pertama dan kedua (jika ada dua belah pihak) hal ini dilakukan dalam upaya adanya kerjasama antara orang tua dan lembaga untuk melakukan koordinasi untuk melakukan tahap berikutnya yaitu tahapan pemecahan masalah/ solusi. Hal ini dilakukan dalam rangka untuk membentuk siswa siswi yang berkarakter dan berakhlak karimah.

Hal ini juga sejalan dengan apa yang disampaikan oleh Ulrih Teicher mengemukakan bahwa manusia masa depan harus mempunyai persyaratan kualitas dan kemampuan sebagai berikut.
a. Fleksibel.
b. Mampu dan bersedia untuk berpartisipasi dalam inovasi serta menjadi kreatif.
c. Mampu menguasai hal-hal yang tidak menentu atau seringkali berubah- ubah.
d. Tertarik dan siap belajar seumur hidup.

e. Memiliki kepekaan sosial dan keterampilan berkomunikasi.

f. Mampu bekerja dalam tim.

g. Mampu mengambil tanggung jawab yang diserahkan padanya.

h. Mampu menyiapkan diri untuk melakukan internasionalisasi pasaran kerja melalui pengertiannya tentang macam-macam budaya.

i. Cakap dalam bebagai hal, baik keterampilan umum, maupun keterampilan profesional.

Hal ini juga sesuai dengan apa yang disampaikan Soedjatmoko yang menggambarkan adanya sifat-sifat dan kemampuan yang harus dimiliki manusia Indonesia di masa mendatang sebagai berikut.

a. Orang harus serba tahu (well informed), dan harus selalu menyadari bahwa proses belajar tidak akan pernah selesai di dalam dunia yang terus berubah secara sangat cepat. Dia harus mampu mencerna informasi yang banyak tapi tuntas, itu artinyaharus mempunyai kemampuan analisis yang tajam, mampu berpikir integratifserta dapat bereaksi cepat.

b. Orang harus kreatif dalam memberikan jawaban terhadap tantangan baru, serta mempunyai kemampuan mengantisipasi setiap perkembangan.

c. Mempunyai kepekaan terhadap keadilan sosial dan solidaritas sosial. Peka terhadap batas-batas toleransi masyarakat serta terhadap perubahan sosial dan ketidakadilan.

d. Memiliki harga diri dan kepercayaan pada diri sendiri berdasarkan iman yang kuat.

e. Sanggup mengidentifikasi dimensidimensi moral dan etis dalam perubahan social dan pilihan teknologi. Selanjutnya juga sanggup menginterpretasikan ketentuanketentuan agama sehingga terungkaplah relevansinya dalam pemecahan masalah dan perkembangan-perkembangan baru. 


\section{Kesimpulan}

1. Upaya mencari sebuah gagasan baru tentang manajemen perubahan di lembaga pendidikan Islam tentu tidaklah mudah, oleh karena itu perlu adanya dukungan dari semua pihak. Pada akhirnya, melalui penelitian ini, diharapkan dapat menghasilkan sebuah solusi tentang manajemen perubahan di lembaga pendidkan Islam di era globalisasi.

2. Pola dasar manajemen paradigma baru melalui proses POAC, yaitu Planning, Organizing, Actuating, dan Controlling, selanjutnya didukung proses penggunaan sumber daya $6 \mathrm{M}$, yaitu Men, Money, Materials, Machines, Methods, dan Markets, dan pengembangan serta perbaikan (improving) terus-menerus agar menjadi lebih baik.

3. Faktor perubahan secara menyeluruh dalam organisasi mencakup enam variabel yang saling berinteraksi yang dapat dimanfaatkan dalam fokus perubahan terencana yaitu Manusiakultur-tugas-tugas, teknologi, desain dan startegi. Keenam variabel tersebut menunjukkan dengan jelas adanya hubungan yang interdependen. Sebuah perubahan pada variabel tertentu biasanya menyebabkan timbulnya perubahan pada salah satu variabel yang lain atau variabel-variabel lainnya.

4. Abad 21 dikenal sebagai era globalisasi. Era globalisasi bukan hanya tantangan , tetapi juga sekaligus mempunyai peluang. Globalisasi memiliki implikasi yang luas tehadap penghidupan dan kehidupan berbangsa dan bernegara, baik ideologi, politik, ekonomi, sosial budaya, maupun pertahanan keamanan.

5. MTsN I Malang yang telah melakukan Manajemen perubahan pada lembaganya dalam menanggapi perubahan di era globalisasi. Adapun langkah-langkah perubahan tersebut adalah dengan melakukan delapan langkah, yaitu : 1) Standar isi, berupa kurikulum, 2) Standar proses yaitu pembelajaran, 3) Standar kelulusan yang di mulai dari pembinaan kepada siswa, 4) Standar pendidik dam kependidikan, 5) Standar sarana prasarana, 6)Standar pengelolaan 7) Standar pembiayaan 8) Standar penilaian

6. Selain delapan langkah di atas, langkahlangkah strategis yang dilakukan MTsN I Malang dalam melakukan perubahan lembaga di era globalisasi ini adalah dengan melakukan MOU/perjanjian dengan Negara lain seperti Malaysia, juga melakukan pengayaan computer dalam memberikan bekal kepada siswa, selain iku juga melakukan KIR (karya ilmiah remaja) secara berjenjang.

7. Keberhasilan dalam melakukan pengelolaan lembaga di MTsN I Malang tak lepas dari faktor pendukung antara lain :

a. Faktor lingkungan. Melalui lingkungan yang kondusif yang menciptakan orang untuk selalu berkembang, hal ini bisa dilakukan melalui perkumpulan musyawarah guru mata pelajaran. Adanya riwart dan phunishment, yang diberikan ketika guru melakukan prestasiprestasi seperti guru mampu membuat modul, lomba guru semalang dan lain sebagainya, dan phunishmen ketika bagi guru atau pegawai yang memang melakukan penyimpangan-penyimpangan.

b. Adanya motivasi individu. Adanya motivasi tersendiri dari guru maupun karyawan yang ingin selalu berkembang yang di buktikan dengan adanya karya-karya yang telah dibuat.

c. Adanya kerjasama yang baik dengan pengurus komite yang selalu mendukung program pengembangan di MTsN I Malang

8. Dalam melaksanakan pengelolaan lembaga di MTsN I Malang juga tak lepas dari faktor penghambat antara lain :

a. Keberagaman orang tua. adanya orang tua yg selalu mendukung proses pembelajaran siswa sehingga siswa bisa meraih prestasi sesuai dengan harapan sekolah, tetapi juga adanya permasalahan orang tua yang terbawa oleh siswa sehingga 
menghambat proses pembelajaran siswa itu sendiri.

b. Penyimpangan siswa. Tidak semua siswa mematuhi tata tertib sekolah, adanya siswa yang menyimpang dari aturan tata tertib sekolah sehingga siswa selalu di pantau oleh Guru mata pelajaran (mapel), wali kelas, guru bimbingan konseling dan tim tata tertib siswa.

\section{Daftar Pustaka}

Burhanuddin. 1994. Analisis Administrasi Manajemen dan Kepemimpinan Pendidikan. Jakarta: Bumi Aksara.

Handoko, T. Hani. 2003. Manajemen. Yogyakarta:BPFE.

Hasibuan, Malayu S.P. 2001. Manajemen; Dasar, Pengertian, dan Masalah (edisi Revisi), Jakarta: Bumi Aksara

Maksum. 1999. Madrasah Sejarah \& Perkembangannya. Jakarta:Logos.
Mulyana, $\quad$ Rohmad. 2004. Mengartikulasikan Pendidikan Nilai, cet kesatu. Bandung: Alfabeta.

Rencana strategis direktorat tenaga kependidikan tahun 2006 - 2010

Siregar, Ali Basyah, Samadhi, T.M.A. Ari (Ed.), Manajemen, Institut Teknologi Bandung.

Undang-Undang RI No. 20 Tahun 2003 tentang SISDIKNAS dan Peraturan Pemerintah RI No. 47 tahun 2008 Tentang Wajib Belajar, Bandung, Citra Umbara, 2008

Wibowo. 2006. Managing Change Pengantar Manajemen Perubahan. Bandung: Alfabeta.

Winardi. 2010. Manajemen Perubahan, The Manajemen of change. Jakarta: Kencana, prenada Media Group. 